BIP: Jurnal Bahasa Indonesia Prima

Vol. 3, No. 2, 2021, September 2021, PP.

\title{
PEMEROLEHAN BAHASA PADA ANAK USIA 33 BULAN BERDASARKAN MEAN LENGTH UTTERANCE (MLU)
}

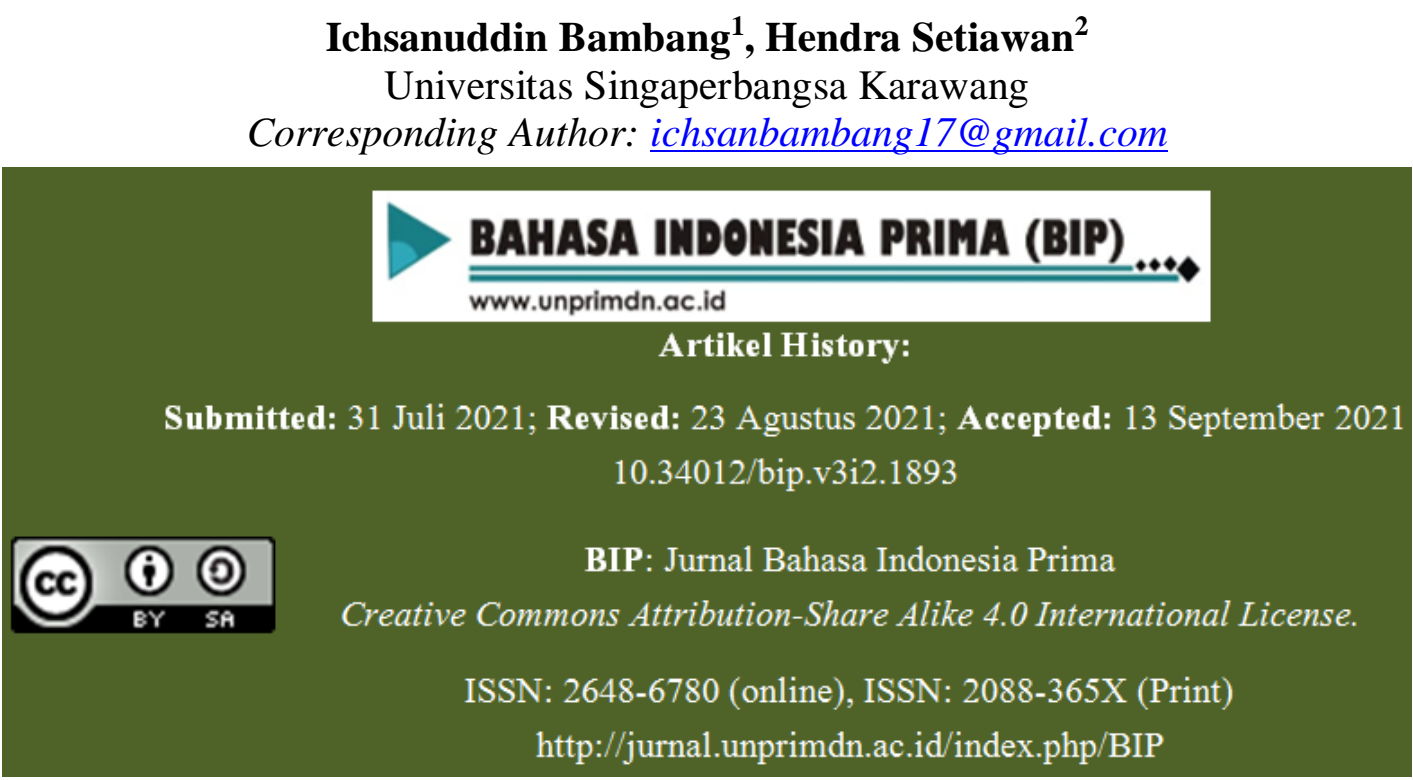

Abstrak-Penelitian ini bertujuan untuk menganalisis pemerolehan bahasa pada anak usia 33 bulan bernama Zahra Zaqiyatun Nufus. Penelitian dilakukan dengan perhitungan berdasarkan Mean Length Utterance (MLU).Penelitian ini bermaksud untuk mengetahui pemerolehan bahasa anak dari segi tuturan dan juga pengenalan anak terhadap jenis kata dan pola kalimat.Penelitian ini menggunakan metode deskriptif kualitatif berupa deskripsi tentang pemerolehan bahasa anak yang dihasilkan. Teknik pengumpulan data dilakukan dengan cara observasi dan dokumentasi yang mana peneliti berinteraksi langsung dengan subjek penelitian setiap hari. Data dikumpulkan dengan dokumentasi menggunakan alat rekam dan alat catat. Teknik analisis data dilakukan dengan cara menghitung pemerolehan bahasa dari data yang telah ditranskrip berdasarkan Mean Length Utterance (MLU). Data yang didapat juga dideskripsikan mengenai pengenalan anak terhadap jenis kata dan pola kalimat. Hasil pemerolehan bahasa yang di dapat berdasarkan perhitungan Mean Length Utterance (MLU) anak yaitu 2,9 yang mana termasuk kategori normal. Anak juga telah mengenal jenis kata berupa nomina, verba, adjektiva, adverbia, dan numeralia.Untuk pola kalimat anak telah mampu menuturkan pola kalimat dasar seperti FN+FN, FN+FV, FN+FAdj, dan FN+Adv.

Kata kunci: psikolinguistik, pemerolehan bahasa, mean length utterance (mlu), kata, kalimat

Abstract-This study aims to analyze language acquisition in a 33 month old child named Zahra Zaqiyatun Nufus. The study was conducted with calculations based on the Mean Length Utterance (MLU). This study intends to determine children's language acquisition in terms of speech and also children's introduction to types of words and sentence patterns. This study uses a qualitative descriptive method in the form of a description of the resulting children's language acquisition. Data collection techniques were carried out by means of observation and documentation in which researchers interacted directly with research subjects every day. Data was collected by documentation using recording equipment and note taking tools. The data analysis technique was carried out by calculating the language acquisition of the transcribed data based on the Mean Length Utterance (MLU). The data obtained is also described about the child's introduction to the types of words and sentence patterns. The language acquisition results obtained are based on the calculation of the child's Mean Length Utterance (MLU), which is 2.9 which is included in the normal category. Children also know the types of words in the form of nouns, verbs, adjectives, adverbs, and 
numerals. For sentence patterns, children have been able to say basic sentence patterns such as $F N+F N, F N+F V, F N+F A d j$, and $F N+A d v$.

Keywords: psycholinguistics, language acquisition, mean length utterance (mlu), words, sentences

\section{A. Pendahuluan}

Bahasa merupakan unsur yang sangat fundamental dalam kehidupan manusia.Dalam kesehariannya, manusia bisa melakukan segala aktivitas yang ditopang dengan bahasa sebagai pengantar. Manusia menggunakan bahasa untuk mengungkapkan gagasan dan perasaan. Bahasa bisa digunakan untuk hal sederhana sampai kepada memengaruhi pemikiran banyak orang. Bahasa juga merupakan wujud kebudayaan yang dimiliki oleh manusia. Manusia yang berbahasa adalah manusia yang memiliki budaya, dan budaya merupakan sesuatu yang harus dijaga dan dilestarikan.

Setiap manusia dilahirkan sudah pasti akan memeroleh bahasa pertama atau yang disebut bahasa ibu. Pemerolehan bahasa sendiri merupakan proses yang masih menjadi fokus banyak penelitian hingga saat ini. Bagaimana seorang anak untuk memperoleh bahasa banyak dijadikan dasar penelitian bagi para peneliti untuk selanjutnya meneliti pembelajaran bahasa. Dalam proses menguasai bahasa ibu atau B1, anak cenderung banyak mengikuti perkataan dari orang terdekat dan lingkungannya. Bahasa awal yang dikenal dan dikuasai anak adalah bahasa yang sederhana dan mendasar. Proses anak untuk menguasai bahasa ibu berlangsung dengan kondusif dalam keluarga dan lingkungannya. Anak akan meniru perkataan dari keluarga dan akan digunakan oleh anak untuk kepentingannya. Secara sederhana, seseorang sejak ia dilahirkan sudah memiliki kemampuan untuk berkomunikasi, meskipun tidak secara verbal. Baru kemudian setelah menguasai bahasa ibu, anak tersebut menggunakan bahasa yang ia peroleh untuk berkomunikasi secara verbal.
Poerwo (dalam Chaer, 2002, hlm.229230) menjelaskan bahwa keadaan bayi baru lahir sampai usia satu tahun lazim disebut dengan istilah infant yang artinya 'tidak mampu berbicara'. Istilah ini memang tepat kalau dikaitkan dengan kemampuan berbicara atau berbahasa. Namun, kurang tepat atau tidak tepat kalau dikaitkan dengan kemampuan berkomunikasi, sebab meskipun "tanpa bahasa" bayi sudah dapat atau sudah melakukan komunikasi dengan orang yang memeliharanya, misalnya dengan tangisan, senyuman, atau gerak-gerik tubuh. Oleh karena itu, barangkali dalam tahap perkembangan bahasa bayi (kanak-kanak) dapat dibagi dua, yaitu (1) tahap perkembangan artikulasi, dan (2) tahap perkembangan kata dan kalimat.

Proses pemerolehan bahasa anak merupakan kajian yang menarik karena masih banyak perdebatan mengenai bagaimana anak bisa memperoleh dan menguasai bahasa ketika belum terjadi perkembangan psikologis yang maksimal karena usia yang masih belia. Chaer (2002, hlm. 221) menjelaskan terdapat dua pandangan kontroversial yang dikemukakan oleh pakar dari Amerika perihal teori perkembangan bahasa anak, yaitu pandangan nativisme dan pandangan behaviorisme. Pandangan nativisme adalah pandangan yang berpendapat bahwa penguasaan bahasa pada kanak-kanak bersifat alamiah (nature).Sementara pandangan behaviorisme adalah pandangan yang berpendapat bahwa penguasaan bahasa pada kanak-kanak bersifat suapan (nurture). Sementara Pranowo (2014, hlm.75) mengatakan bahwa hipotesis pemerolehan dan belajar bahasa adalah hipotesis yang menyatakan bahwa anak kecil dalam proses menguasai bahasa pertama terjadi secara ambang sadar dan bersifat alamiah. 
Pemerolehan bahasa pada seorang anak merupakan hal yang sulit untuk dijelaskan. Seorang anak tanpa melakukan pembelajaran secara formal dan terstruktur bisa dengan cepat menguasai bahasa pertamanya. Dalam memperoleh bahasa bisa dipengaruhi oleh beberapa hal, seperti kemampuan kognitif anak tersebut sampai lingkungan di mana ia berada. Kedua hal tersebut sangat berpengaruh bagi pemerolehan bahasa maupun perkembangannya bagi seorang anak. Masih menjadi perhatian juga bagaimana seorang anak dapat memperoleh fonologi, morfologi, sintaksis, dan semantik. Penghitungan pemerolehan bahasa yang diujarkan oleh anak dapat dihitung dengan Mean Length Utterance (MLU). MLU merupakan sebuah cara untuk menghitung ujaran lingual yang dihasilkan oleh anak. Secara umum menghitung MLU adalah dengan membagi jumlah morfem dengan jumlah ujaran dari anak.Jumlah ujaran yang dihitung lazimnya 50 sampai 100 ujaran. Pada penelitian kali ini akan dihitung MLU dari subjek penelitian bernama Zahra Zaqiatun Nufus yang pada saat dilakukan penelitian masih berusia 33 bulan. Penelitian ini juga akan menelaah pemerolehan bahasa anak dari aspek jenis kata dan pola kalimat yang diujarkan.

\section{Pskolinguistik}

Menurut Chaer (2009, hlm. 5) secara etimologi sudah disinggung bahwa kata psikolinguistik terbentuk dari kata psikologi dan kata linguistik, yakni dua bidang ilmu yang berbeda, yang masingmasing berdiri sendiri, dengan prosedur dan metode yang berlainan. Namun, keduanya sama-samaa meneliti bahasa sebagai objek formalnya. Hanya objek materialnya yang berbeda, linguistik mengkaji struktur bahasa, sedangkan psikologi mengkaji perilaku berbahasa atau proses berbahasa. Dengan demikian cara dan tujuannya juga berbeda. Diperlukan hubungan kerja sama untuk mendalami dan mengkaji bahasa secara lebih komprehensif.
Psikolinguistik merupakan ilmu yang dikaji untuk menemukan jawaban tentang teori bahasa yang berhubungan dengan psikologis. Menurut Chaer (2009, hlm. 56) secara teoretis tujuan utama psikolinguistik adalah mencari satu teori bahasa yang secara linguistik bisa diterima dan secara psikologi dapat menerangkan hakikat bahasa dan pemerolehannya. Dengan kata lain, psikolinguistik mencoba menerangkan hakikat struktur bahasa, dan bagaimana struktur ini diperoleh, digunakan pada waktu bertutur, dan pada waktu memahami kalimat-kalimat dalam pertuturan itu.

Pateda (2015, hlm. 56-57) mengemukakan bahwa seorang linguis dapat memanfaatkan psikologi untuk menganalisis perolehan bahasa bahkan penampilan bahasa akibat gangguan psikologis. Psikolinguistik adalah ilmu yang mempelajari bahasa akibat latar belakang kejiwaan penutur bahasa. Pada psikolinguistik dipelajari pula proses perolehan bahasa seseorang. Dengan demikian ilmu psikologis merupakan unsur yang memiliki kaitan sangat erat dan tidak bisa dipisahkan dari kasus-kasus linguistik seseorang.

\section{Pemerolehan Bahasa}

Pemerolehan bahasa merupakan proses yang akan dilalui oleh setiap anak yang mana banyak sekali kajian yang menganalisis pemerolehan bahasa anak untuk menemukan jawaban dari mengapa anak bisa memeroleh bahasa tanpa mempelajarinya secara terstruktur. Chaer (2009, hlm. 167) menjelaskan pemerolehan bahasa atau akuisisi adalah proses yang berlangsung di dalam otak seorang anak ketika dia memeroleh bahasa pertamanya atau bahasa ibunya. Pemerolehan bahasa biasanya dibedakan dari pembelajaran bahasa (language learning). Pembelajaran bahasa berkaitan dengan proses-proses yang terjadi pada waktu seorang kanak-kanak mempelajari bahasa kedua setelah dia mempelajari bahasa pertamanya.Jadi, pemerolehan bahasa berkenaan dengan bahasa pertama, 
sedangkan pembelajaran bahasa berkenaan dengan bahasa kedua.

Chaer (2009, hlm. 167) juga menjelaskan ada dua proses yang terjadi ketika seorang kanak-kanak sedang memperoleh bahasa pertamanya, yaitu proses kompetensi dan proses performansi. Kedua proses ini merupakan dua proses yang berlainan. Kompetensi adalah proses penguasaan tata bahasa yang berlangsung secara tidak disadari. Proses kompetensi ini menjadi syarat untuk terjadinya proses performansi yang terdiri dari dua buah proses, yakni proses pemahaman dan proses penerbitan atau proses menghasilkan kalimat-kalimat. Proses pemahaman melibatkan kemampuan atau kepandaian mengamati atau kemampuan mempersepsi kalimat-kalimat yang didengar. Sedangkan penerbitan melibatkan kemampuan mengeluarkan atau menerbitkan kalimat-kalimat sendiri. Kedua jenis proses kompetensi ini apabila telah dikuasai kanak-kanak akan menjadi kemampuan linguistik kanak-kanak itu. Jadi, kemampuan linguistik terdiri dari kemampuan memahami dan kemampuan melahirkan atau menerbitkan kalimatkalimat baru yang dalam linguistik transformasi generatif disebut perlakuan, atau pelaksanaan bahasa, atau performansi.

Chomsky (dalam Chaer, 2009, hlm. 168) membagi kompetensi pemerolehan bahasa menjadi tiga buah komponen tata bahasa, yaitu komponen sintaksis, komponen semantik, dan komponen folonogi. Oleh karena itu, pemerolehan bahasa ini lazim juga dibagi menjadi pemerolehan semantik, pemerolehan sintaksis, dan pemerolehan fonologi.Chaer (2009, hlm. 168) melanjutkan, ke dalam pemerolehan sintaksis dan semantik termasuk juga pemerolehan leksikon atau kosa kata. Ketiga komponen tata bahasa ini tidaklah diperoleh secara bersaingan, yang satu terlepas dari yang lain, melainkan diperoleh secara bersamaan. Sebelum membicarakan pemerolehan ketiga komponen tersebut, yang perlu dibicarakan terlebih dahulu adalah beberapa teori hipotesis yang berkaitan dengan masalah pemerolehan bahasa itu sendiri.Ketiga teori tersebut adalah hipotesis nurani, hipotesis tabularasa, dan hipotesis kesemestaan kognitif.

Chaer (2009, hlm. 168-180) menjelaskan ketiga teori yang berkaitan dengan pemerolehan bahasa sebagai berikut:

\section{a) Hipotesis Nurani}

Setiap bahasawan mampu memahami dan membuat kalimat-kalimat dalam bahasanya karena ia telah menyimpan dalam nuraninya tata bahasa yang kemudian menjadi kecakapan bahasanya. Anak juga telah menguasai kemampuankemampuan perormansi bahasa itu.Jadi, dalam pemerolehan bahasa, kelas yang diperoleh oleh kanak-kanak adalah kompetensi dan performansi bahasanya. Kemudian tata bahasa itu sendiri terdiri dari komponen sintaksis, semantik, dan fonologi, dan dalam setiap komponen itu memiliki rumus atau kaidah.Selain dari rumus-rumus komponen tersebut, untuk bisa memahami dan membuat kalimatkalimat perlu juga terlebih dahulu dikuasai atau dimiliki rumus-rumus yang mengubah bentuk-bentuk dalam atau struktur dalam menjadi bentuk luar atau struktur luar.

Lenneberg dan Chomsky (dalam Chaer, 2009, hlm. 168-169) menjelaskan perihal pengamatan yang dilakukan terhadap pemerolehan bahasa pada kanakkanak yang melahirkan hipotesis nurani, hasil pengamatan tersebut adalah sebagai berikut.

1) Semua kanak-kanak yang normal akan memeroleh bahasa ibunya asal saja "diperkenalkan" pada bahasa ibunya itu. Maksudnya, dia tidak diasingkan dari kehidupan ibunya (keluarganya).

2) Pemerolehan bahasa tidak ada hubungannya dengan kecerdasan kanak-kanak. Artinya, baik anak yang cerdas maupun yang tidak cerdas akan memeroleh bahasa itu.

3) Kalimat-kalimat yang didengar kanak-kanak sering kali tidak 
gramatikal, tidak lengkap, dan jumlahnya sedikit.

4) Bahasa tidak dapat diajarkan kepada makhluk lain; hanya manusia yang dapat berbahasa.

5) Proses pemerolehan bahasa oleh kanak-kanak dimanapun sesuai dengan jadwal yang erat kaitannya dengan proses pematangan jiwa kanak-kanak.

6) Struktur bahasa sangat rumit, kompleks, dan bersifat universal. Namun, bahasa dapat dikuasai kanakkanak dalam waktu yang relatif singkat, yaitu dalam waktu antara tiga atau empat tahun saja.

Simanjuntak (dalam Chaer, 2009, hlm. 169) menjelaskan mengenai hipotesis nurani, perlu dibedakan adanya dua macam hipotesis nurani, yaitu hipotesis nurani bahasa dan hipotesis nurani mekanisme. Chaer (2009, hlm. 169) menjelaskan hipotesis nurani bahasa merupakan satu asumsi yang menyatakan bahwa sebagian atau semua bagian dari bahasa tidaklah dipelajari atau diperoleh tetapi ditentukan oleh fitur-fitur nurani yang khusus dari organisme manusia. Sedangkan hipotesis nurani mekanisme menyatakan bahwa proses pemerolehan bahasa oleh manusia ditentukan oleh perkembangan kognitif umum dan mekanisme nurani umum yang berinteraksi dengan pengalaman. Maka bedanya kedua hipotesis ini adalah bahwa hipotesis nurani bahasa menekankan terdapatnya sesuatu "benda" nurani yang dibawa sejak lahir yang khusus untuk bahasa dan berbahasa. Sedangkan hipotesis nurani mekanisme terdapatnya suatu "benda" nurani berbentuk mekanisme yang umum untuk semua kemampuan manusia. Bahasa dan berbahasa hanyalah sebagian saja dari yang umum itu.

Chomsky dan Miller (dalam Chaer, 2009, hlm. 169-170) mengatakan adanya alat khusus yang dimiliki kanak-kanak sejak lahir untuk dapat berbahasa. Alat itu namanya language acquisition device
(LAD) yang berfungsi untuk memungkinkan seorang kanak-kanak memeroleh bahasa ibunya. Cara kerja LAD adalah apabila sejumlah ucapan yang cukup memadai dari suatu bahasa (bahasa apa saja): Sunda, Arab, Cina, dan sebagainya) "diberikan" kepada LAD seorang kanak-kanak sebagai masukan (input), maka LAD itu akan membentuk salah satu tata bahasa formal sebagai keluaran (output)-nya.

b) Hipotesis Tabularasa

Chaer (2009, hlm. 172-173) menjelaskantabularasa secara harfiah berarti 'kertas kosong', dalam artian belum ditulisi apa-apa. Lalu, hipotesis tabularasa ini menyatakan bahwa otak bayi pada waktu dilahirkan sama seperti kertas kosong, yang nanti akan ditulis atau diisi denganpengalaman-pengalaman. Hipotesis ini pada mulanya dikemukakan oleh John Locke seorang tokoh empirisme yang sangat terkenal; kemudian dianut dan disebarluaskan oleh John Watson seorang tokoh terkemuka aliran behaviorisme dalam psikologi. Dalam hal ini, menurut hipotesis tabularasa, semua pengetahuan dalam bahasa manusia yang tampak dalam perilaku berbahasa adalah merupakan hasil dari integrasi peristiwa-peristiwa linguistik yang dialami dan diamati oleh manusia itu. Sejalan dengan hipotesis ini, behaviorisme menganggap bahwa pengetahuan linguistik terdiri hanya dari rangkaian hubunganhubungan yang dibentuk dengan cara pembelajaran S - R (Stimulus - Respons). Cara pembelajaran $\mathrm{S}-\mathrm{R}$ yang terkemuka adalah pelaziman klasik, pelaziman operan, dan mediasi atau penengah yang telah dimodifikasi menjadi teori-teori pembelajaran bahasa.

c) Hipotesis Kesemestaan Kognitif

Sinclair de Zwart (dalam Chaer, 2009, hlm. 178) menjelaskan bahwa dalam kognitifisme hipotesis kesemestaan kognitif yang diperkenalkan oleh Piaget telah digunakan sebagai dasar untuk menjelaskan proses-proses pemerolehan bahasa pada kanak-kanak. Chaer menambahkan, Piaget sendiri sebenarnya 
tidak pernah secara khusus mengeluarkan satu teori mengenai pemerolehan bahasa karena beliau menganggap bahasa merupakan satu bagian dari perkembangan kognitif (intelek) secara umum. Piaget hanya mengkaji perkembangan kognitif umum ini, dan dalam pengkajian ini beliau telah mengeluarkan sebuah hipotesis mengenai kesemestaan kognitif, termasuk bahasa. Namun para pengikut Piaget di jenewa telah meluaskan pandangan Piaget ini sehingga satu teori pemerolehan bahasa dalam kognitifisme telah dirumuskan.

Chaer (2009, hlm. 178-179) memaparkan teori yang didasarkan pada kesemestaan kognitif, bahasa diperoleh berdasarkan struktur-struktur kognitif deriamotor. Struktur-struktur ini diperoleh kanak-kanak melalui interaksi dengan benda-benda atau orang-orang disekitarnya. Urutan pemerolehan ini secara garis besar sebagai berikut.

1) Antara usia 0 sampai 1,5 tahun (0:01:6) kanak-kanak mengembangkan pola-pola aksi dengan cara bereaksi terhadap alam sekitarnya. Pola-pola inilah yang kemudian diatur menjadi struktur-struktur akal atau mental.

2) Setelah struktur aksi dinuranikan, maka kanak-kanak memasuki tahap representasi kecerdasan, yang terjadi antara usia dua tahun sampai 7 tahun.

3) Setelah tahap representasi kecerdasan, dengan representasi simboliknya, berakhir, maka bahasa kanak-kanak semakin berkembang, dan dengan mendapat nilai-nilai sosialnya.

Ketika dilahirkan, seorang anak Setiap anak yang normal akan belajar bahasa pertama (bahasa ibu) dalam tahun-tahun pertamanya dan proses itu terjadi hingga kira-kira umur lima tahun (Nababan, 1992, hlm. 72). Dalam proses perkembangan, semua anak manusia yang normal paling sedikit memperoleh satu bahasa alamiah. Dengan kata lain, setiap anak yang normal atau mengalami pertumbuhan yang wajar memperoleh sesuatu bahasa, yaitu bahasa pertama atau bahasa ibu dalam tahun- tahun pertama kehidupannya, kecuali ada gangguan pada anak tersebut.

Proses pemerolehan bahasa merupakan suatu hal yang kontroversial antara para ahli bahasa. Permasalahan yang diperdebatan antara para ahli adalah pemerolehan bahasa yang bersifat nuture dan nature (Dardjowidjojo, 2010, hlm. 235). Ahli bahasa yang menganut aliran behaviorisme mengatakan bahwa pemerolehan bahasa bersifat nurture, yakni pemerolehan ditentukan oleh alam lingkungan. Ahli bahasa lain mengatakan manusia dilahirkan dengan suatu tabula rasa, yakni semacam piring kosong tanpa apa pun. Piring tersebut kemudian diisi oleh alam termasuk bahasanya. Dengan demikian pemerolehan bahasa anak merupakan proses yang sangat dipengaruhi oleh keadaan kognitif dan lingkungan sekitarnya.

B1 diperoleh melalui beberapa tahap. Menurut Nababan (1992, hlm. 78) ada empat tahap yang dialami anak dalam pemerolehan bahasa pertama diantaranya sebagai berikut.

a) Tahap pengocehan. Tahap pengocehan dimulai dari usia enam bulan ketika anak mulai mengucapkan sejumlah bunyi yang belum bermakna. Sebagian kecil ujaran tersebut terkesan bermakna dan terjadi secara kebetulan saja.

b) Tahap satu kata sata frase. Tahap ini dimulai kira-kira pada usia satu tahun. Pada usia tersebut anak mulai menggunakan serangkaian bunyi berulang untuk makna yang sama. Anak sudah mengerti bahwa bunyi ujaran berkaitan dengan makna. Tahap ini sama dengan satu kata yang diucapkan anak itu merupakan satu konsep yang lengkap. Dalam bentuknya, kata-kata yang diucapkan anak terdiri atas konsonan $(\mathrm{m} / \mathrm{p} / \mathrm{s} / \mathrm{k})$ dan vokal $(\mathrm{a} / \mathrm{i} / \mathrm{u} / \mathrm{e} / \mathrm{o})$.

c) Tahap dua kata, satu frase. Tahap ini dialami oleh anak berusia kira-kira dua tahun. Anak mulai mengucapkan ujaran yang terdiri atas dua kata. 
Dalam taha ini, anak menggunakan rangkaian dari ucapan satu kata dengan intonasi seakan-akan ada dua ucapan.

d) Tahap menyerupai telegram. Pada usia lebih dari dua tahun, umumnya anak sudah menggunakan ujaran kalimat lengkap. Hubungan sintaktik sudah mulai tampak jelas. Misalnya, konstruksi kalimat agen+aksi+ojek, seperti Dinda naik mobil.

\section{Pemerolehan Sintaksis}

Dardjowidjojo (2010, hlm. 248) menjelaskan Pemerolehan sintaksis pada anak anak dimulai pada usia kurang dari 2:0tahun. Pada usia tersebut anak sudah bisa menyusun kalimat dua kata atau lebih twoword utterance 'Ujaran Dua Kata' (UDK). Anak mulai dengan dua kata yangdiselingi jeda sehingga seolah-olah dua kata itu terpisah. Dengan adanya dua katadalam UDK maka orang dewasa dapat lebih bisa menerka apa yang dimaksud oleh anak karena cakupan makna menjadi lebih terbatas. UDK sintaksisnya lebih kompleks dan semantiknya juga semakin jelas. Dengan demikian, pemerolehan sintaksis pada anak berkaitan dengan kata atau kalimat yang telah mampu diucapkan oleh anak tersebut.

Sementara Chaer (2009, hlm. 183) mengemukakan banyak pakar pemerolehan bahasa menganggap bahwa pemerolehan sintaksis dimulai ketika kanak-kanak mulai dapat menggabungkan dua buah kata atau lebih (lebih kurang ketika berusia 2:0 tahun). Jika kanakkanak telah mencapai tahap dua kata atau lebih, ucapan-ucapannya juga menjadi semakin banyak, dan mudah ditafsirkan. Oleh karena itulah, penyelidik lebih cenderung untuk memulai kajian pemerolehan bahasa itu pada tahap dua kata.

\section{Pengukuran Mean Length Of Utterance (MLU)}

Mean Length of Utterance (MLU) merupakan pengukur untuk perkembangan sintaksis anak. Menurut Brown (dalam Dardjowidjojo, 2010, hlm. 241) cara menghitung MLU dapat dilakukan dengan beberapa langkah, pertama mengambil sampel sebanyak 100 ujaran. Kedua, menghitung jumlah morfemnya. Ketiga, membagi jumlah morfem dengan jumlah ujaran. Seperti pada rumus berikut.

$M L U=\frac{\text { Jumlah Morfem }}{\text { Jumlah Ujaran }}$

Brown (1973) membagi tahap pemerolehan bahasa anak berdasarkan MLU anak menjadi enam tahap, yaitu :

a) Tahap I $M L U(1-1,5)$ pada usia 1222 bulan

b) Tahap II $M L U(1,5-2,0)$ pada usia 22-28 bulan

c) Tahap III $M L U(2,0-2,25)$ pada usia 27-28 bulan

d) Tahap IV $M L U(2,25-2,5)$ pada usia 28-30 bulan

e) Tahap V $M L U(2,5-2,75)$ pada usia 31-32 bulan

f) Tahap VI $M L U(2,75-30,0)$ pada usia 33-34 bulan

g) Tahap VII $M L U(3,0-3,5)$ pada usia 35-39 bulan

h) Tahap VIII $M L U(3,5-3,45)$ pada usia 38-40 bulan

i) Tahap IX $M L U(3,5-3,45)$ padausia 41-46 bulan

j) Tahap X $M L U(45+)$ pada usia +47 bulan.

\section{B. Metode Penelitian}

\section{Metodologi Penelitian}

Metodologi penelitian yang digunakan dalam penelitian ini adalah metode desktiptif kualitatif. Menurut Sugiyono (2016, hlm. 9), metode penelitian kualitatif adalah metode penelitian yang berlandaskan pada filsafat postpositivisme, digunakan untuk meneliti pada kondisi obyek yang alamiah, (sebagai lawannya eksperimen) dimana peneliti adalah sebagai instrumen kunci, pengambilan sampel sumber data dilakukan secara triangulasi (gabungan), analisis data bersifat induktif atau kualitatif, dan hasil penelitian kualitatif lebih menekankan makna dari pada generalisasi.

Menurut Arikunto (2006, hlm. 192) metode penelitian adalah cara yang 
digunakan oleh peneliti dalam mengumpulkan satuan penelitiannya. Metode penelitian yang digunakan pada penelitian ini adalah metode penelitian kualitatif. Metode kualitatif dipilih agar bisa mendeskripsikan dan menginterpretasikan perihal pemerolehan bahasa pada anak usia 33 bulan.

Berdasarkan pengertian tersebut peneliti berusaha mendeskripsikan bahasa yang diucapkan oleh subjek penelitian yang berlandaskan pada pengukuran Mean Length of Utterance (MLU) serta menjelaskan pemerolehan bahasa dari aspek jenis kata dan pola kalimat.

\section{Sumber Data}

Penelitian ini menggunakan sumber data dari anak bernama Zahra Zaqiatun Nufus ketika berusia 33 bulan. Alamat bertempat di Perumahan Karang Anyar Residence Blok C8/1, Karangbahagia, Kabupaten Bekasi. Pengembilan data dilakukan secara natural melalui interaksi peneliti dan subjek penelitian dalam kehidupan sehari-hari.

\section{Teknik Pengumpulan Data}

Teknik pengumpulan data dalam penelitian kali ini menggunakan teknik observasi dan dokumentasi. Jenis observasi yang dilakukan adalah observasi partisipatif, peneliti sambil mengamati subjek penelitian juga ikut dalam keseharian dengan berinteraksi secara natural. Setiap ujaran yang dikeluarkan oleh subjek penelitian didokumentasikan dengan menggunakan rekaman suara juga dengan teknik catat atau transkrip. Data yang dikumpulkan sebanyak 100 tuturan anak yang diambil sebagai sampel untuk pengukuran $M L U$ anak tersebut.

\section{Teknik Analisis Data}

Teknik analisis data dilakukan dengan beberapa langkah, pertama mentranskrip data yang diperoleh dari subjek penelitian, data tersebut berupa 100 ujaran yang dikeluarkan. Selanjutnya menghitung jumlah morfem dari ujaran yang dikeluarkan subjek penelitian. Setelah mengetahui jumlah morfem maka dihitung $M L U$ anak tersebut. Setelah diketahui angka $M L U$-nya, kemudian dijelaskan interpretasi dari hasil $M L U$ yang diperoleh termasuk normal atau tidak dalam hal pemerolehan bahasa. Kemudian dijelaskan pemerolehan bahasa dari aspek jenis kata dan pola kalimat.

\section{Hasil dan Pembahasan}

Hasil ujaran yang diucapkan oleh subjek penelitian adalah sebagai berikut.

\section{Kalimat Satu Kata}

1. Kejar

2. Berbi (Barbie)

3. Tutupnya

4. Sebel (Sebal)

5. Assalamulaikum (Assalamualaikum)

6. Gatel (Gatal)

7. Sonoh (Sana)

8. Mamah

\section{Kalimat Dua Kata}

1. Awas kamu

2. Abang Isan

3. Mo mnum (Mau minum)

4. Yaudah deh

5. Ada apa

6. Duit aku

7. Minta dong

8. Mana liat (Mana lihat)

9. Udah siang (sudah siang)

10. Kamu nakal

11. Main dong

12. Gara-gara kamu

13. Ngga ah (tidak ah)

14. Pake motor (menggunakan motor)

15. Jangan stop

16. Ngga mao (Ngga mau)

17. Lani tunggu

18. Yudah sonoh (Yaudah sana)

19. Becanda lagi

20. Siapa ya?

21. Udah abis (Sudah habis)

22. Waw enak

23. Aku dokternya

24. Orang rame-rame

\section{Kalimat Tiga Kata}

1. Aku mao tolat (Aku mau salat)

2. Ganti baju dulu

3. Mam pake jengkol (Makan pake jengkol)

4. Tunggu aku woi 
BIP: Jurnal Bahasa Indonesia Prima Vol. 3, No. 2, 2021, September 2021, PP.

5. Aku bantuin mamah (aku bantu mamah)

6. Ayo kita bantuin (ayo kita bantu)

7. Mainan ini aja (kita main ini saja)

8. Ayo abang Isan

9. Ga ada bohong (tidak ada bohong)

10. Satu dua tiga

11. Kamu jangan berisik

12. Mana aku minjem (mana aku pinjam)

13. Aku mao baso (Aku mau bakso)

14. Eh ngga boleh (eh tidak boleh)

15. Nama kamu siapa?

16. Ayah aku mana

17. Aku nantuk ah (Aku kantuk ah)

18. Hape kamu dincas (ponsel kamu dicas)

19. Itu hape siapa? (itu ponsel siapa)

20. Kamu udah sembuh?

21. Aku mao sekola (Aku mau sekolah)

22. Mao makan jengkol (Mau makan jengkol)

23. Buat di warung

24. Mana ya tadi

25. Vika mah pelit

26. Aku mau tidur

27. Pintu udah dikonci (Pintu sudah dikunci)

28. Ikut dong plis (Ikut dong please)

29. Kan masih kuat

30. Sendal siapa ini? (sandal siapa ini)

31. Lagi bikin peye (Sedang bikin peyek)

32. Awas ada kerudung

33. Jangan diapus ya (Jangan dihapus $y a)$

34. Maen ujanan yu (Main hujan yu)

35. Aku ganti baju

36. Tuh burung keujanan (Tuh burung kehujanan)

37. Ditutup aja pintunya

38. Udah jangan banyak-banyak (sudah jangan banyak-banyak)

39. Itu ibu gurunya

40. Ini punya aku

41. Lah bodo amat

42. Ante Opi saur (Tante Opi sahur)

43. Iya main apa?

44. Kamu sakit ya?

45. Sikat gigi dulu
46. Ambil ngga apa-apa (ambil saja tidak apa-apa)

\section{Kalimat Empat Kata}

1. Ada ucing di sini (Ada kucing di sini)

2. Udah ah aku cape (Sudah ah aku capai)

3. Main yu sama aku

4. Pelit ga usah temen (pelit tidak usah temenin)

5. Jangan nih punya kamu

6. Aku ada banyak nih

7. Aku mao ke ayah (Aku mau ke ayah)

8. Kamu kan ganti baju

9. Ini aku masih bayi (ini waktu aku masih bayi)

10. Baru bangun dede bayinya

11. Yaudah sono di luar (Yaudah sana di luar)

12. Biarin dia mah jatoh (biarin dia jatuh)

13. Jangan ambil masker ini

14. Yaudah deh ini aja (ya sudah yang ini saja)

15. Aku ini kamu itu (aku yang ini dan kamu yang itu)

\section{Kalimat Lima Kata}

1. Ambilin bantal guling aku dong (tolong ambilkan bantal guling aku)

2. Kamu jangan bangunin aku ya

3. Aku udah ngga bedarah lagi (aku sudah tidak berdarah lagi)

4. Nanti bikin kue bulu ya (Nanti bikin kue bolu ya)

5. Kamu mah kepalanya ngga gini (kamu mah kepalanya tidak seperti ini)

6. Punya kamu mah ngga jadi (punya kamu tidak jadi)

\section{Kalimat Enam Kata}

1. Aku tidur di situ aja deh

Berikut adalah perhitungan Mean Length Utterance $(M L U)$ dari subjek penelitian. 
Tabel 1.Perhitungan $M L U$ Subjek

\begin{tabular}{|l|c|c|}
\multicolumn{1}{|c|}{ Pumlah } \\
$\begin{array}{c}\text { Kata Per } \\
\text { Tuturan }\end{array}$ & $\begin{array}{c}\text { Jumlah } \\
\text { Tuturan }\end{array}$ & $\begin{array}{c}\text { Jumlah } \\
\text { Morfem }\end{array}$ \\
\hline $\begin{array}{l}\text { Kalimat satu } \\
\text { kata }\end{array}$ & 8 & 8 \\
\hline $\begin{array}{l}\text { Kalimat dua } \\
\text { kata }\end{array}$ & 24 & 48 \\
\hline $\begin{array}{l}\text { Kalimat tiga } \\
\text { kata }\end{array}$ & 46 & 138 \\
\hline $\begin{array}{l}\text { Kalimat } \\
\text { empat kata }\end{array}$ & 15 & 60 \\
\hline $\begin{array}{l}\text { Kalimat lima } \\
\text { kata }\end{array}$ & 6 & 30 \\
\hline $\begin{array}{l}\text { Kalimat } \\
\text { enam kata }\end{array}$ & 1 & 6 \\
\hline Total & $\mathbf{1 0 0}$ & $\mathbf{2 9 0}$ \\
\hline
\end{tabular}

$M L U=\frac{\text { Jumlah Morfem }}{\text { Jumlah Ujaran }}$

MLU $=\frac{290}{100}$

$M L U=2,9$

$M L U=$ Mean Length Utterance

Berdasarkan hasil penemuan dan perhitungan $M L U$, hasil yang didapat adalah 2,9. Sejalan dengan teori Brown mengenai $M L U$ (mean lengthof utterance), skor 2,9 terdapat pada tahap VI rentang usia 33 sampai dengan 34 bulan yaitu dalam rentang 2,75-3,0. Berdasarkan perhitungan tersebut, usia subjek penelitian adalah 33 bulan dan mendapat hasil 2,9 kata per tuturan dan dapat disimpulkan bahwapemerolehan bahasa subjek penelitian dalam produksi kosakata bersifat normal sesuai dengan teori $M L U$ Brown. Subjek penelitian mampu mengucapkan kalimat satu kata sampai dengan kalimat enam kata.

Berdasarkan data yang diperoleh, subjek penelitian sudah mampu mengenal jenis kata berupa nomina $(\mathrm{N})$, verba $(\mathrm{V})$, adjektiva (Adj), adverbia (Adv), dan numeralia (Num).

$\mathrm{N}=$ Berbi (boneka barbie), Mamah (ibu), Ayah, Lani, Vika, Ucing (kucing), Baso (bakso), Abang, jengkol, dsb.
$\mathrm{V}=$ Kejar, minum, minta, makan, tidur, bikin, dsb.

Adj = nakal, enak, berisik, pelit, sakit, banyak, dsb.

Adv = sana, di warung, di sini, di luar, di situ, ngga (tidak), dsb.

Num = satu, dua, tiga, banyak, dsb.

Sementara dari segi pola kalimat, berdasarkan data yang diperoleh, subjek penelitian mampu berujar dengan pola dasar seperti $\mathrm{FN}+\mathrm{FN}, \mathrm{FN}+\mathrm{FV}, \mathrm{FN}+\mathrm{FAdj}$, dan $\mathrm{FN}+\mathrm{Adv}$.

$\mathrm{FN}+\mathrm{FN}=$ abang Isan.

$\mathrm{FN}+\mathrm{FV}=$ ante Opi saur (tante Opi sahur).

$\mathrm{FN}+\mathrm{FAdj}=$ Vika pelit, Lani tunggu .

$\mathrm{FN}+\mathrm{Adv}=$ ada ucing di sini (ada kucing di sini).

\section{Simpulan}

Simpulan yang didapat berdasarkan hasil penelitian terhadap subjek penelitian yang berusia 33 bulan adalah sebagai berikut.

1. Hasil perhitungan Mean Length Utterance (MLU) terhadap subjek yang berusia 33 bulan adalah 2,9 kata per tuturan, dan dapat disimpulkan bahwapemerolehan bahasa subjek penelitian dalam produksi kosakata bersifat normal sesuai dengan teori $M L U$ Brown. Dalam teori Brown mengenai $M L U$ (mean lengthof utterance), skor 2,9 terdapat pada tahap VI rentang usia 33 sampai dengan 34 bulan yaitu dalam rentang 2,75-3,0.

2. Subjek penelitian telah mampu bertutur mulai dari satu kata sampai lima kata, dengan demikian tuturan yang dihasilkan oleh subjek penelitian sudah cukup lengkap.

3. Subjek penelitian mamu menuturkan beberapa jenis kata yaitu nomina, verba, adjektiva, adverbia, dan numeralia, yang merupakan termasuk kategori lengkap.

4. Subjek penelitian mampu menuturkan pola kalimat dasar seperti $\mathrm{FN}+\mathrm{FN}$, $\mathrm{FN}+\mathrm{FV}, \mathrm{FN}+\mathrm{FAdj}$, dan FN + Adv. 


\section{Daftar Pustaka}

Chaer, Abdul. 2009. Psikolingusitik Kajian Teoritik. Jakarta: Rineka Cipta.

Pranowo. 2014. Teori Belajar Bahasa. Yogyakarta: Pustaka Pelajar.

Pateda, Mansoer. 2015. Linguistik Sebuah Pengantar. Bandung: CV Angkasa.

Simanjuntak, Maria. "Pemerolehan Bahasa Anak (KajianMean Length of Utterance 'MLU') Luzca

Fortunata Roito Situmorang (Anak Usia Satu Tahun Sebelas Bulan)". Universitas Negeri Medan, 3-5.

Nurjamiaty. "Pemerolehan Bahasa Anak UsiaTiga Tahun Berdasarkan Tontonan Kesukaannya Ditinjau Dari Konstruksi Semantik", 42-62.

Triadi, Rai Bagus. 2017. "Studi Kasus Akuisisi Bahasa Pada Anak Usia 4 Tahun (KajianPsikolinguistik)". Sasindo Unpam, 4(1), 9-10.

Marsis dan Witri Annisa. 2018. "Pemerolehan Bahasa Anak di Sumatera Barat (Kajian Mean Length of Utterance [MLU])". Lingua :Jurnal Bahasa, Sastra, dan Pengajarannya Fakultas Bahasa dan Seni, Universitas Negeri Semarang, 14(1), 37-38.

Darjowodjojo, $\quad$ Soenjono. 2010. Psikolinguistik: Pengatar Pemahaman Bahasa Manusia. Jakarta: Yayasan Obor Indonesia.

Sugiyono. 2016. Metode Penelitian Kuantitatif Kualitatif dan $R \& D$. Bandung: Alfabeta.

Arikunto, Suharsimi. 2006. Prosedur Penelitian: Suatu Pendekatan Praktik
Edisi Revisi VI. Jakarta: PT Rineka Cipta. 